\title{
The Use of Wound Dressings Based \\ on Cellulose in Patients \\ with Purulent Diseases of Soft Tissues
}

\author{
Yuri S. Vinnik ${ }^{a}$, Nadezhda M. Markelova*a, \\ Ekaterina I. Shishatskaya ${ }^{b}$, Mihail N. Kuznetsov', \\ Svetlana V. Prudnikova ${ }^{d}$ and Nataliya S. Soloveva ${ }^{a}$ \\ ${ }^{a}$ V.F. Vojno-Yasenetsky Krasnoyarsk State Medical University \\ 1 Partizan Zheleznyak Str., Krasnoyarsk, 660022, Russia \\ ${ }^{b}$ Institute of Biophysics of $S B R A S$ \\ 50/50 Akademgorodok, Krasnoyarsk, 660036, Russia \\ ${ }^{c}$ Railway Hospital st. Krasnoyarsk OAO RJD \\ 47 Lomonosova str., Krasnoyarsk, 660027, Russia \\ ${ }^{d}$ Siberian Federal University \\ 79 Svobodny, Krasnoyarsk, 660041, Russia
}

The paper presents the results of clinical trials of wound dressing based on cellulose in comparison with wound dressing "Gidrokoll" in patients with acute purulent soft tissue infections. It is proved that the wound covering based on cellulose more efficient, contribute to the rapid and intensive purification and epithelialization of infected wounds.

Keywords: wound covering, cellulose, purulent wound, wound dressing, wound infection.

DOI: $10.17516 / 1997-1389-2015-9-1-121-129$.

(C) Siberian Federal University. All rights reserved

* Corresponding author E-mail address: markelova_nadya@mail.ru 


\title{
Применение раневого покрытия на основе целлюлозы
}

\section{у больных с гнойными заболеваниями мягких тканей}

\author{
Ю.С. Винник ${ }^{a}$ Н.М. Маркелова ${ }^{a}$, Е.И. Шишацкая ${ }^{\tilde{}}$, \\ М.Н. Кузнецовв ${ }^{\text {, С.В. Прудникова }}{ }^{\mathrm{r}}$, Н.С. Соловьева ${ }^{\mathrm{a}}$ \\ ${ }^{a}$ Красноярский государственный медицинский университет \\ им. проф. В.Ф. Войно-Ясенеикого \\ Россия, 660022, Красноярск, ул. Партизана Железняка, 1 \\ ${ }^{6}$ Институт биофизики СО РАН \\ Россия, 660036, Красноярск, Академгородок, 50/50 \\ ${ }^{\circ}$ Дорожная клиническая больница на ст. Красноярск \\ Россия, 660027, Красноярск, ул. Ломоносова, 47 \\ ${ }^{2}$ Сибирский федеральный университет \\ Россия, 660041, Красноярск, пр. Свободный, 79
}

В статье представлены результаты клинических испытаний раневого покрытия на основе иеллюлозы, нагруженного диоксидином, в сравнении с раневым покрытием «Гидроколл». Доказано, что при лечении больных с острой гнойной инфекиией мягких тканей раневое покрытие на основе иеллюлозы более эффективно, способствует быстрому и интенсивному очищению и эпителизации инфицированных ран.

Ключевые слова: раневое покрытие, целлюлоза, гнойная рана, раневая повязка, раневая инфекция.

\section{Введение}

В настоящее время число пациентов с гнойными заболеваниями мягких тканей продолжает неуклонно расти, несмотря на значительные достижения хирургии, иммунологии, микробиологии, биохимии, связанные с расширением и углублением знаний об этиологии, патогенезе, клинике хирургической инфекции (Богданец и др., 2009; Туманов и др., 2000). Данная проблема остается актуальной в связи с тяжелым течением раневого процесса, сохранением тенденции к возрастанию количества хронических и рецидивирующих процессов. Гнойная инфекция наблюдается в 35-45 \% случаев от общего числа хирургических заболеваний и протекает в виде острых и хронических бо- лезней или нагноения послеоперационных или посттравматических ран (Винник и др., 2013; Grigoras et al., 2010). Наиболее актуально для практической хирургии решение вопроса о местном лечении. Перспективно использование раневых покрытий разнонаправленного действия, сочетающих в себе антисептики, антибиотики, вещества, стимулирующие процессы репарации и эпителизации, воздействуя на все фазы раневого процесса. Любая раневая повязка должна удовлетворять следующим основным условиям: эффективно удалять избыток раневого экссудата и его токсических компонентов, обеспечивать адекватный газообмен между раной и атмосферой, предотвращать вторичное инфицирование раны и контамина- 
цию объектов окружающей среды, способствовать созданию оптимальной влажности раневой поверхности, обладать антиадгезивными свойствами, иметь достаточную механическую прочность (Абаев, 2004). Для повышения лечебного воздействия в состав повязок включают лекарственные средства различной направленности действия. В последние годы разработаны технологии физической и химической модификации перевязочных материалов с иммобилизацией на поверхности лекарственных препаратов, что обеспечивает их медленное высвобождение и длительное лечебное воздействие (Адамян и др., 2001).

Цель исследования - сравнение эффективности лечения больных с острой гнойной инфекцией мягких тканей с помощью раневого покрытия на основе бактериальной целлюлозы, нагруженного диоксидином, обладающим бактерицидным действием и раневого покрытия «Гидроколл».

\section{Материалы и методы}

Ограниченные клинические испытания целлюлозных раневых покрытий, нагруженных антисептическим препаратом диоксидином, проведены в Дорожной клинической больнице на ст. Красноярск ОАО РЖД с разрешения локального этического комитета.

В качестве продуцента целлюлозы использован штамм Komagataeibacter xylinus IBP/SFU-MG PV0, выделенный из природной ассоциации Medusomyces gisevii J. Lindau (чайный гриб) селекционным путем на стандартной среде Hestrin-Schramm (HS). Штамм Komagataeibacter xylinus IBP/SFU-MG PV0 депонирован во Всероссийской коллекции промышленных микроорганизмов (ВКПМ) (коллекционный номер ВКПМ В-12068) и запатентован [Патент РФ на изобретение № 2568605].
Для получения пленок бактериальной целлюлозы (БЦ) штамм выращивали на агаризованной среде Hestrin-Schramm (HS), содержащей ( $\%, \mathrm{w} / \mathrm{v})$ : глюкозу -2, пептон $-0,5$, дрожжевой экстракт - 0,5, $\mathrm{Na}_{2} \mathrm{HPO}_{4}-0,27$ и лимонную кислоту $-0,115$. Далее колонии бактерий переносили в колбу с жидкой средой HS и культивировали в течение 3 сут при температуре $30{ }^{\circ} \mathrm{C}$ в статических условиях. Для получения композитных пленок из БЦ и поли(3-гидроксибутирата) были изготовлены мембраны из ультратонких волокон поли(3гидроксибутирата) методом электростатического формования с помощью установки для получения нановолокона NANON-01A (MECC Co., Ltd, Япония). Мембраны стерилизовали $\mathrm{H}_{2} \mathrm{O}_{2}$-плазмой в стерилизаторе Sterrad NX (Джонсон \&Джонсон, США). Стерильную мембрану накладывали на поверхность пленок БЦ трехсуточной культуры, после чего культивировали еще 3 сут.

Полученную композитную пленку отделяли от культуральной жидкости, очищали в 0,5\%-м растворе $\mathrm{NaOH} 24$ ч при температуре $25-27^{\circ} \mathrm{C}$, затем помещали в $0,5 \%$-й раствор соляной кислоты на 24 ч для нейтрализации, после чего промывали дистиллированной водой до $\mathrm{pH}$ 7. Пленки стерилизовали автоклавированием в фосфатно-буферном растворе при $121^{\circ} \mathrm{C}$ в течение 15 мин и хранили в стерильном растворе или высушивали на воздухе при комнатной температуре до постоянной массы. Массу сырой и сухой пленки определяли на лабораторных весах Adventurer OH-AR2140 (Ohaus, Швейцария). Приготовленные пленки помещали в $1 \%$-й стерильный раствор диоксидина на 30 мин.

В экспериментальную группу были включены десять пациентов с острой гнойной инфекцией мягких тканей (абсцессы, флегмоны, флегмонозно-некротическая форма рожистого воспаления нижних конечностей, тро- 
фические язвы на фоне венозных нарушений и сахарного диабета). У этих больных в комплексе традиционного местного лечения применяли разработанные раневые покрытия на основе целлюлозы. Группу сравнения составили четырнадцать больных с аналогичной патологией; в качестве раневого покрытия были использованы повязки «Гидроколл». Группы больных были сопоставимы по возрасту, полу, характеру гнойных заболеваний мягких тканей, площади ран. Сроки наблюдения за пациентами колебались от 14 до 42 сут.

Методы исследования включали: измерение клинико-лабораторных показателей, клиническую оценку раневого процесса, $\mathrm{pH}$ метрию, лазерную допплеровскую флоуметрию.

При клинической оценке раневого процесса учитывали сроки исчезновения отека, появление единичных грануляций, заполнение ран зрелой грануляционной тканью, начало эпителизации и наступление полной эпителизации. Для этого использовали систему оценки динамики раневого процесса, представленную в табл. 1.

Статистическая обработка полученных данных выполнялась при помощи программы Statistica 6.0 (StatSoft).

\section{Результаты и обсуждение}

Результаты измерения клиниколабораторных показателей у больных приведены в табл. 2, из которой видно, что на фоне применения экспериментального целлюлозного раневого покрытия уже на 2-е сутки после операции отмечалось снижение температуры тела. К 6-7-м суткам послеоперационного периода температура не превышала $37{ }^{\circ} \mathrm{C}$. Достоверное снижение показателей эндотоксикоза было отмечено уже на 3-и сутки лечения. Так, количество лейкоцитов в крови у больных экспериментальной группы составило $\left(16,3 \pm 1,3 \cdot 10^{9}\right)$ кл/л $(\mathrm{p}<0,05)$, а к 10 -м суткам лечения этот показатель не превышал нормального уровня - $\left(8,8 \pm 1,3 \cdot 10^{9}\right)$ кл/л $(\mathrm{p}<0,05)$. Анализ лабораторных данных при поступлении больных в стационар выявил высокий уровень эндогенной интоксикации. В первые сутки лечения лейкоцитарный индекс интоксикации составлял $(5,24 \pm 2,12)$ ед., на фоне проводимого лечения достоверное снижение этого показателя происходило к 5 -м суткам - $(2,98 \pm 0,43)$ ед. $(\mathrm{p}<0,05)$.

Изучение микроциркуляции показало, что у больных в контрольной группе значения тканевой перфузии ран были выше, чем в 10 см от раневой зоны $(13,2 \pm 1,3$ перф. ед.). После очищения раны и стихания явле-

Таблица 1. Применяемая система оценки результатов лечения

\begin{tabular}{|l|c|c|c|}
\hline \multirow{2}{*}{\multicolumn{1}{|c|}{ Критерии оценки }} & \multicolumn{3}{|c|}{ Результаты лечения (сут) } \\
\cline { 2 - 4 } & Хорошие & Удовлетворительные & Неудовлетворительные \\
\hline $\begin{array}{l}\text { Исчезновение } \\
\text { перифокального отека }\end{array}$ & $<4$ & $5-8$ & $>9$ \\
\hline $\begin{array}{l}\text { Появление единичных } \\
\text { грануляций }\end{array}$ & $<6$ & $7-10$ & $>16$ \\
\hline $\begin{array}{l}\text { Заполнение ран зрелой } \\
\text { грануляционной тканью }\end{array}$ & $<10$ & $11-16$ & $>17$ \\
\hline $\begin{array}{l}\text { Появление краевой } \\
\text { эпителизации }\end{array}$ & $<11$ & $12-17$ & $>35$ \\
\hline Полная эпителизация & $<30$ & $31-35$ & $>$ \\
\hline
\end{tabular}




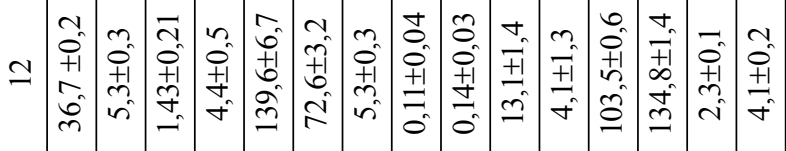

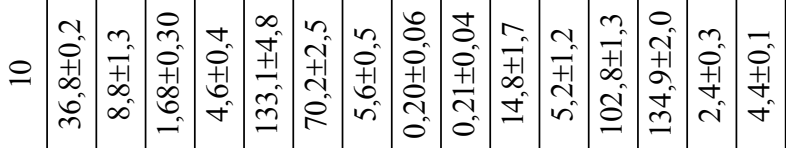

을

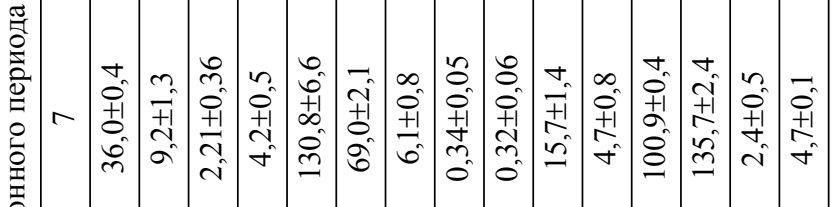

$\stackrel{\varrho}{\stackrel{0}{\leftrightarrows}}$

峝

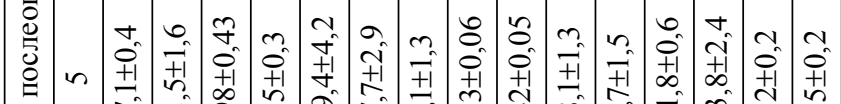

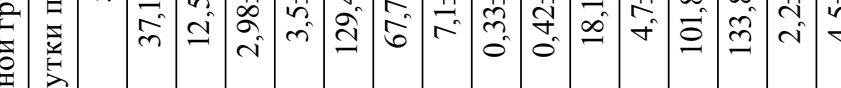

궁

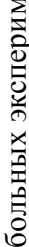

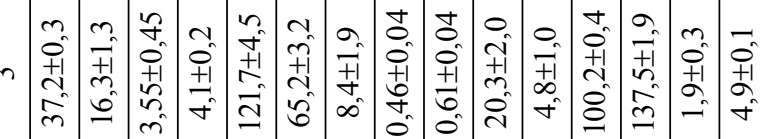

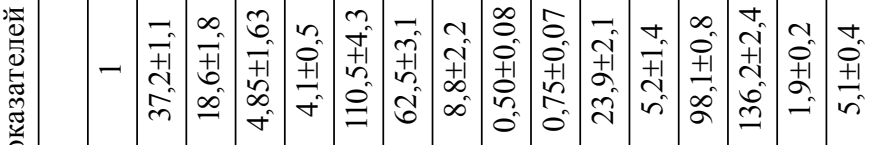

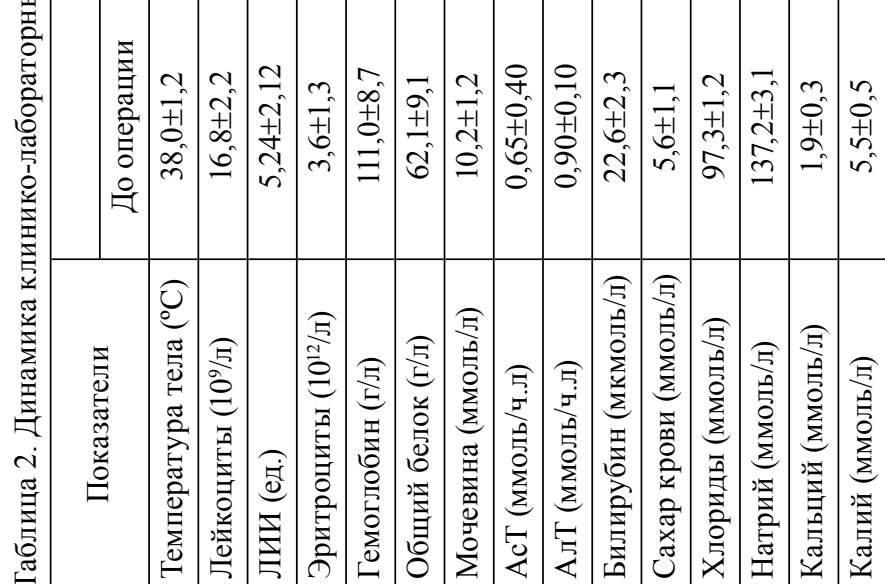


ний воспаления показатели микрокровотока уменьшались. Достоверное снижение зарегистрировано на 7-8-е сутки - $(11,2 \pm 0,55)$ перф. ед. У больных экспериментальной группы значения тканевой перфузии ран существенно не отличались от контрольной, они были выше, чем в 10 см от раневой зоны и составляли в паравульнарной зоне $(14,4 \pm 1,5)$ перф. ед. По мере очищения раны и стихания явлений воспаления показатели микрокровотока уменьшались. Достоверное снижение зарегистрировано на 7-18-е сутки - $(9,6 \pm 0,74)$ перф. ед.

Результаты лечения демонстрирувют, что в контрольной группе переход раневого процесса во вторую фазу был длительным, у
7 (46,1 \%) больных к 45-м суткам эпителизация не завершилась (табл. 3). Метод лечения ран в экспериментальной группе пациентов значительно снижал уровень рН, приближая течение раневого процесса к наиболее оптимальным значениям. Оценка скорости заживления ран свидетельствовала о хороших и удовлетворительных результатах. В исследуемой группе пациентов к 42-м суткам у 9 (88,9 \%) пациентов наступила полная эпителизация ран (табл. 4). При сопоставлении данных $\mathrm{pH}$ со скоростью заживления ран были выявлены однонаправленные изменения между качеством течения раневого процесса и значением водородного показателя раневой поверхности. Проведенный кор-

Таблица 3. Оценка результатов лечения в контрольной группе

\begin{tabular}{|l|c|c|c|}
\hline \multicolumn{1}{|c|}{\begin{tabular}{c}
\multirow{2}{*}{$\begin{array}{c}\text { Критерии оценки } \\
\text { динамики }\end{array}$} \\
\cline { 2 - 4 }
\end{tabular}} & Хорошие & Удовлетворительные & Неудовлетворительные \\
\hline $\begin{array}{l}\text { Исчезновение } \\
\text { перифокального отека }\end{array}$ & - & $2(6,7 \%)$ & $12(93,3 \%)$ \\
\hline $\begin{array}{l}\text { Появление единичных } \\
\text { грануляций }\end{array}$ & - & $2(6,7 \%)$ & $12(93,3 \%)$ \\
\hline $\begin{array}{l}\text { Заполнение ран зрелой } \\
\text { грануляционной тканью }\end{array}$ & - & $4(29,8 \%)$ & $10(70,2 \%)$ \\
\hline $\begin{array}{l}\text { Появление краевой } \\
\text { эпителизации }\end{array}$ & - & $1(14,4 \%)$ & $13(84,6 \%)$ \\
\hline Полная эпителизация & $3(22,1 \%)$ & $4(30,8 \%)$ & $7(46,1 \%)$ \\
\hline
\end{tabular}

Таблица 4. Оценка результатов лечения в экспериментальной группе

\begin{tabular}{|l|c|c|c|}
\hline \multirow{2}{*}{ Критерии оценки } & \multicolumn{2}{|c|}{ Результаты лечения (число пациентов и \% от общего числа) } \\
\cline { 2 - 4 } & Хорошие & Удовлетворительные & Неудовлетворительные \\
\hline $\begin{array}{l}\text { Исчезновение } \\
\text { перифокального отека }\end{array}$ & $6(66,9 \%)$ & $3(22,8 \%)$ & $1(10,3 \%)$ \\
\hline $\begin{array}{l}\text { Появление единичных } \\
\text { грануляций }\end{array}$ & $6(56,6 \%)$ & $4(43,4 \%)$ & - \\
\hline $\begin{array}{l}\text { Заполнение ран зрелой } \\
\text { грануляционной тканью }\end{array}$ & $6(66,7 \%)$ & $4(33,3 \%)$ & $1(11,1 \%)$ \\
\hline $\begin{array}{l}\text { Появление краевой } \\
\text { эпителизации }\end{array}$ & $5(66,9 \%)$ & $9(88,9 \%)$ & $3(20,2 \%)$ \\
\hline Полная эпителизация & \multicolumn{2}{|c|}{$2(12,9 \%)$} & \\
\hline
\end{tabular}


реляционный анализ между значением $\mathrm{pH}$ и скоростью заживления ран выявил сильную отрицательную связь между этими показателями: по мере увеличения $\mathrm{pH}$ раны скорость заживления ее снижается. Коэффициент корреляции Спирмена равен 0,9 .

Таким образом, предложенный авторский способ позволяет оптимизировать раневой процесс, сократить время появления грануляций и заполнения ран зрелой грануляционной тканью на 3- и 3-14-е сутки соответственно, повысить частоту эпителизации на 29,8 \% по сравнению с традиционной терапией.

Примеры успешного клинического применения раневых покрытий на основе бак- териальной целлюлозы представлены на рис. 1-4.

\section{Заключение}

Раневое покрытие на основе бактериальной целлюлозы обеспечивает более быстрое и интенсивное очищение и эпителизацию инфицированных ран. При смене повязки некрозы, фрагменты разрушенных клеток и микроорганизмы удаляются вместе с ней. Покрытие служит матрицей для образования новой ткани в фазе регенерации. Предпосылкой для более быстрого заживления раны является образование равномерного, хорошо васкуляризованного участка, который может служить основой

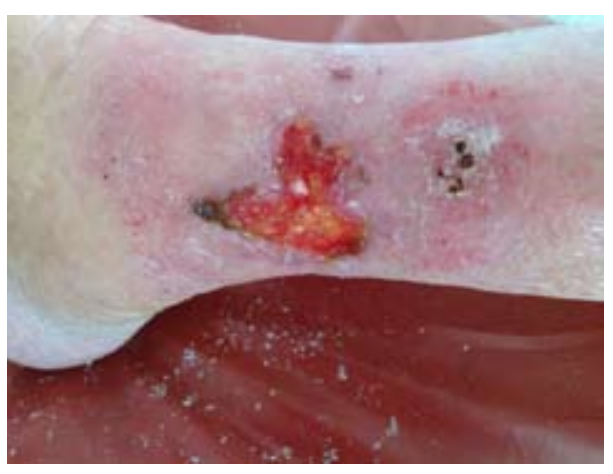

A

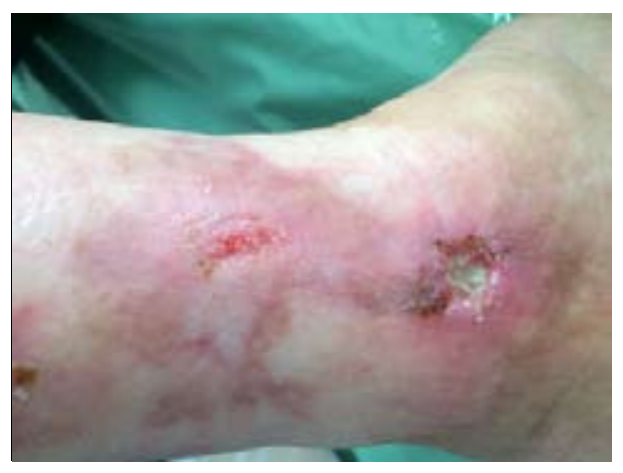

Б

Рис. 1. Больная П., 66 лет. Инфицированная трофическая язва нижней трети левой голени, 5-е сутки очищение дна язвы от гноя, фибрина, намечены процессы краевой эпителизации (А); 4 недели после начала лечения - отмечается положительная динамика к заживлению вторичным натяжением (Б)
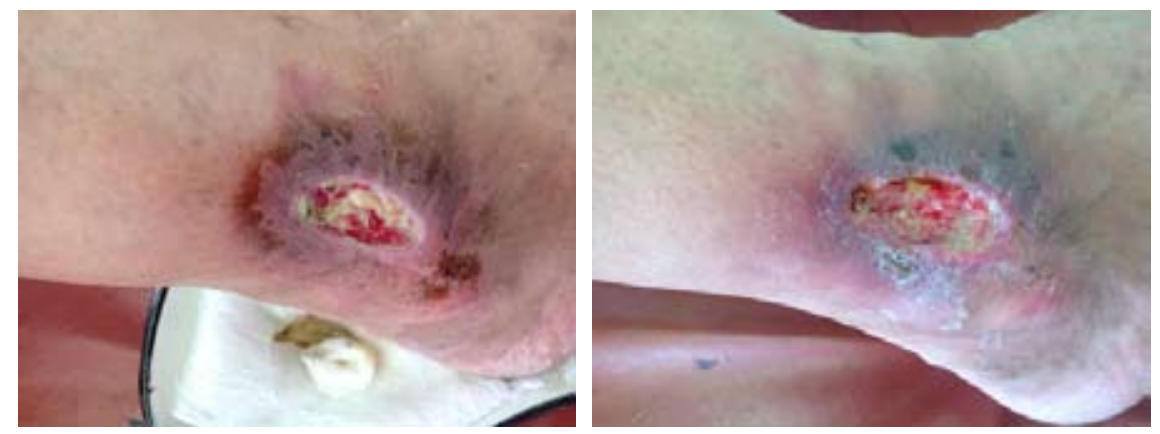

Рис. 2. Больной С., 46 лет. Инфицированная трофическая язва на правой голени, 6-е сутки - очищение дна язвы от гноя, фибрина, намечены процессы краевой эпителизации 

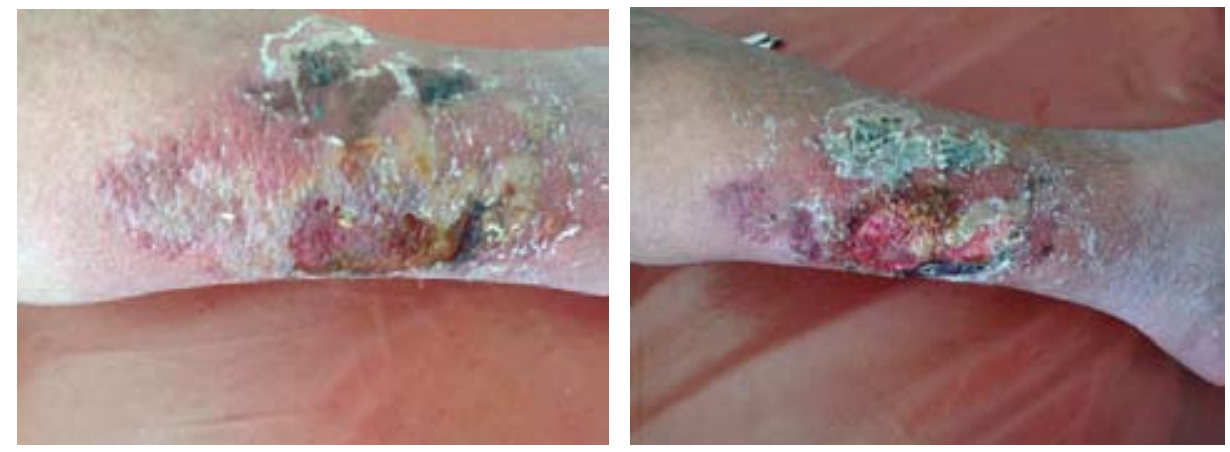

Рис. 3. Больной Б., 36 лет. Буллезная форма рожи левой голени, 9-е сутки - зрелые розовые грануляции, активная краевая эпителизация

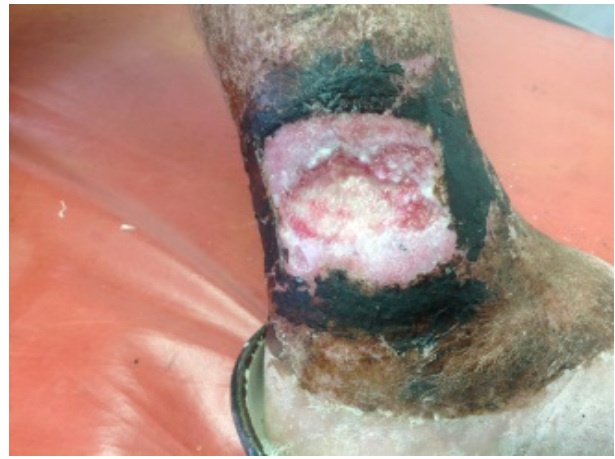

A

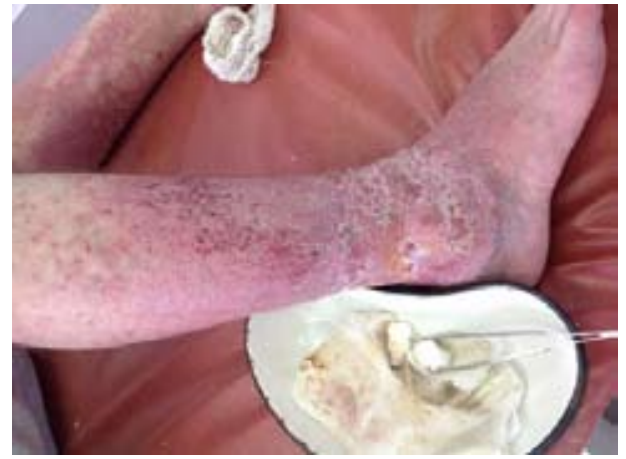

Б

Рис. 4. Больной Р., 50 лет. Инфицированная трофическая язва на правой голени, 5-е сутки - очищение дна язвы от гноя, фибрина, намечены процессы краевой эпителизации (А); 4 недели после начала лечения отмечается положительная динамика к заживлению вторичным натяжением (Б)

для последующей успешной кожной пластики, а также для спонтанной реэпителизации поверхностных ран. Данное раневое покрытие обладает рядом важных функций: служит барьером против возникнове- ния вторичных инфекций, ограничивает потерю жидкости и одновременно с этим обеспечивает необходимую аэрацию раны, а следовательно, и ускорение процессов заживления таких ран.

Работа выполнена за счет средств государственного задания на проведение фундаментальных исследований РАН (проект № гос. регистрации 01201351505).

\section{Список литературы}

Абаев Ю.К. (2004) Перевязочные материалы и средства в хирургии. Вестник хирургии 3: 83-87 [Abaev Yu.K. (2004) Dressings and means of surgery. Herald of Surgery [Vestnik hirurgii], 3: 83-87 (in Russian)]

Адамян А.А., Добыш С.В., Килимчук Л.Е. (2000) Биологически активные перевязочные средства в комплексном лечении гнойно-некротических ран: методические рекомендачии. М., 
Б.и., 40 с. [Adamyan A.A., Dobysh S.V., Kilimchuk L.E. (2000) Bioactive dressings in treatment of necrotic wounds: methodical recommendations. Moscow, B.I., 40 p. (in Russian)]

Богданец Л.И., Березина С.С., Кириенко А.И. (2009) Стимуляция II-III стадии регенерации венозных трофических язв гидроактивными раневыми покрытиями. Хирургия. Журнал им. Н.И. Пирогова, 6: 61-66 [Bogdanets L.I., Berezina S.S., Kirienko A.I. (2009) Stimulation of stage II-III regeneration trophic venous ulcers by hydroactive dressing. Surgery. N.I. Pirogov Journal [Hirurgiya. Zhurnal im. N.I. Pirogova], 6: 61-66 (in Russian)]

Винник Ю.С., Маркелова Н.М., Тюрюмин В.С. (2013) Современные методы лечения гнойных ран. Сибирское медицинское обозрение, 1: 18-24 [Winnick Yu.S., Markelova N.M., Tyuryumin V.S. (2013) Modern methods of treatment of purulent wounds. Siberian medical review [Sibirskoe medicinskoe obozrenie], 1: 18-24 (in Russian)]

Туманов В.П., Герман Г.С (2000) Методическое руководство по лечению ран. М., Пауль Хартманн, 123 с. [Tumanov V.P., German G.S. (2000) Methodological guidelines for the treatment of wounds. Moscow, Paul Hartmann, 123 p. (in Russian)]

Grigoraş C., Jitaru D., Topala I., Ungureanu D., Florea I., Dumitraşcu N., Bădescu M. (2010) Planimetric and histologic study of epidermal regeneration under plasma pretreated occlusive wound dress. Annals of the Romanian Society for Cell Biology, 15(1): 61-70 